\title{
Hubungan Obesitas Remaja dengan Hipertrofi Ventrikel Kanan berdasarkan Pemeriksaan Elektrokardiografi
}

\author{
Shinta Larasaty, Julistio Djais, Sri Endah Rahayuningsih \\ Departemen/SMF Ilmu Kesehatan Anak FK Universitas Padjadjaran /RS Dr. Hasan Sadikin Bandung
}

\begin{abstract}
Latar belakang. Perubahan distribusi lemak viseral dan subkutan menyebabkan remaja berisiko mengalami obesitas. Obesitas sering dikaitkan dengan hipoksia kronik akibat obesity hypoventilation syndrome, yang dapat menyebabkan hipertensi pulmonal dan hipertrofi ventrikel kanan.

Tujuan. Mengetahui hubungan obesitas remaja dengan hipertrofi ventrikel kanan berdasarkan pemeriksaan EKG.

Metode. Studi komparatif dengan rancangan potong lintang, dilakukan Juli-September 2010, pada remaja laki-laki dan perempuan berusia 12-15 tahun dengan obesitas dan gizi normal, di SMPN 14 dan SMPN 17 Bandung. Diagnosis hipertrofi ventrikel kanan ditegakkan berdasarkan pemeriksaan EKG (kriteria voltase). Uji eksak Fisher digunakan untuk mengetahui hubungan antara jenis kelamin dan kriteria diagnosis hipertrofi ventrikel pada obesitas, serta hubungan obesitas dan hipertrofi ventrikel kanan. Hubungan dinyatakan bermakna bila $\mathrm{p}<0,05$.

Hasil. Penelitian melibatkan 126 subjek yang terdiri atas 33 remaja laki-laki obes, 30 remaja perempuan obes, 32 remaja laki-laki gizi normal, dan 31 remaja perempuan gizi normal. Hasil interpretasi EKG berupa hipertrofi ventrikel kanan ditemukan pada 27 subjek obes (21,4\%), hipertrofi ventrikel kiri pada 2 subjek obes $(1,6 \%)$ dan satu subjek dengan status gizi normal $(0,8 \%)$, sedangkan hasil interpretasi elektrokardiogram dari 96 subjek $(76,2 \%)$ lainnya dalam batas normal. Gelombang $T$ positif di $V_{1}$ berhubungan dengan obesitas khususnya pada remaja laki-laki ( $<<0,001)$, dan obesitas berhubungan dengan hipertrofi ventrikel kanan $(p<0,001)$.

Kesimpulan. Obesitas remaja berhubungan dengan hipertrofi ventrikel kanan, pemeriksaan EKG menunjukkan ditemukannya gelombang $\mathrm{T}$ positif di $\mathrm{V}_{1}$, khususnya pada remaja laki-laki obes.
\end{abstract}

Sari Pediatri 2011;12(6):391-6.

Kata kunci: elektrokardiografi, hipertrofi ventrikel kanan, obesitas, remaja

Alamat korespondensi:

Dr. Sri Endah R, dr, SpA(K). Bagian/SMF Ilmu Kesehatan Anak FK Unpad/Rumah Sakit Dr. Hasan Sadikin, Jl. Pasteur No. 38 Bandung 40163, Indonesia. Telp. 022-2035957. E-mail: endah.perkani@gmail. com

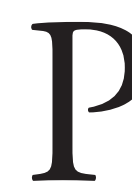

revalens obesitas meningkat di seluruh dunia, dan telah dinyatakan oleh World Health Organization (WHO) sebagai epidemi global yang memerlukan penanganan segera. Data WHO menyebutkan bahwa terdapat sekitar 10\% kasus obesitas pada anak dan remaja yang berusia 5-17 
tahun. Mengacu pada kurva pertumbuhan WHO 2007, obesitas dinyatakan bila skor-Z indeks massa tubuh (IMT) berdasarkan usia dan jenis kelamin berada di atas kurva $2 \mathrm{SB} .{ }^{1}$

Masalah kesehatan yang timbul sebagai akibat obesitas sangat beragam, namun sering dikaitkan dengan berbagai penyakit kardiovaskular. ${ }^{2}$ Kelompok usia remaja (laki-laki usia 12-20 tahun dan 10-18 tahun untuk perempuan) mengalami periode transisional berupa perubahan komposisi tubuh akibat perubahan distribusi lemak viseral dan subkutan, ${ }^{3}$ merupakan periode kritis terkait obesitas. ${ }^{4}$ Pengaruh obesitas terhadap perubahan fungsi jantung telah dilaporkan oleh Zeybek $\mathrm{dkk}^{5}$ dan Wong $\mathrm{dkk}^{6}$ berdasarkan pemeriksaan ekokardiografi. Zeybek $\mathrm{dkk}^{5}$ menemukan bahwa anak dengan obesitas dapat mengalami disfungsi diastolik ventrikel kanan subklinis, selain itu Wong $\mathrm{dkk}^{6}$ menemukan dilatasi ventrikel kanan pada keadaan obesitas. Interaksi berbagai faktor yang menyebabkan insufisiensi respiratorik dan hipoventilasi alveolar diajukan sebagai mekanisme yang mendasari perubahan morfologi sistem kardiovaskular pada penderita obesitas. ${ }^{7}$

Disfungsi ventrikel kanan dan hipertensi pulmonal pada umumnya diketahui berdasarkan pemeriksaan ekokardiografi, tetapi ekokardiografi belum tentu dapat mendeteksi adanya hipertensi pulmonal, terutama jika tidak didapatkan regurgitasi trikuspid yang adekuat. Pemeriksaan ekokardiografi mahal dan tidak setiap pusat kesehatan memiliki sarananya. Elektrokardiografi (EKG) merupakan alat pemeriksaan yang banyak tersedia di pusat kesehatan di Indonesia, dapat digunakan sebagai alat uji tapis dan pemantauan. Pemeriksaan EKG juga merupakan pemeriksaan noninvasif yang mudah dikerjakan dengan biaya yang relatif murah. ${ }^{8}$

Diagnosis hipertrofi ventrikel dapat ditegakkan berdasarkan pemeriksaan EKG dengan analisis kompleks QRS dan gelombang T, yang menggambarkan dinamika kelistrikan ventrikel. ${ }^{9}$ Pada pemeriksaan EKG perlu diperhatikan faktor jenis kelamin, karena amplitudo gelombang $\mathrm{R}$ dan $\mathrm{S}$ berbeda antara kedua jenis kelamin. ${ }^{10}$ Melalui penelitian yang dilaporkan, ingin diketahui hubungan obesitas remaja dengan hipertrofi ventrikel kanan berdasarkan pemeriksaan EKG.

\section{Metode}

Studi komparatif dengan rancangan potong lintang dilakukan selama Juli-September 2010 di SMPN 14 dan SMPN 17 Bandung. Subjek penelitian adalah remaja perempuan dan laki-laki berusia $12-15$ tahun dengan status gizi berdasarkan kurva IMT/umur dari WHO 2007 termasuk dalam kategori status gizi obesitas dan normal. Subjek tidak diikutsertakan apabila menderita penyakit jantung bawaan, penyakit paru kronik, hipoksemia disebabkan kelainan darah atau penyakit ginjal, yang diketahui dengan melakukan wawancara medis serta pemeriksaan fisis lengkap. Diagnosis hipertrofi ventrikel kanan berdasarkan kriteria voltase ditegakkan dengan ditemukannya (salah satu): amplitudo $\mathrm{R}$ di $\mathrm{V}_{1}$ lebih besar dari 13 $\mathrm{mm}$, amplitudo $\mathrm{S}$ di $\mathrm{V}_{6}$ lebih besar dari $4 \mathrm{~mm}$, jumlah aljabar $\mathrm{R}$ di $\mathrm{V}_{1}$ dan $\mathrm{S}$ di $\mathrm{V}_{6}$ lebih besar dari $17 \mathrm{~mm}$, rasio $\mathrm{R} / \mathrm{S}$ di $\mathrm{V}_{1}$ lebih besar dari upper limit of normal (ULN), aksis lebih dari $120^{\circ}$, ditemukan gelombang T positif di $\mathrm{V}_{1}$, atau didapatkan pola $\mathrm{qR}$ maupun RSR' di sandapan prekordium kanan. Pemeriksaan EKG dilakukan dengan menggunakan electrocardiograph FX7000 (Fukuda Denshi Medical Instruments Co.,Ltd), dan selanjutnya elektrokardiogram diinterpretasi oleh konsultan kardiologi anak. Penelitian telah mendapat persetujuan dari Komite Etik FK Universitas Padjadjaran-RS dr. Hasan Sadikin Bandung. Analisis statistik dengan uji eksak Fisher dilakukan untuk mengetahui hubungan jenis kelamin dan kriteria diagnosis hipertrofi ventrikel kanan pada EKG remaja obes, serta mengetahui hubungan obesitas dengan hipertrofi ventrikel kanan. Hubungan dinyatakan bermakna bila $\mathrm{p}<0,05$. Piranti lunak SPSS Statistic ver. 17.0 (Windows) digunakan dalam analisis data.

\section{Hasil}

Penelitian melibatkan 126 subjek yang terdiri atas 33 subjek obes laki-laki, 30 subjek obes perempuan, 32 subjek gizi normal laki-laki, dan 31 subjek gizi normal perempuan. Subjek berusia 12-15 tahun. Karakteristik subjek penelitian tertera pada Tabel 1. Kriteria EKG untuk diagnosis hipertrofi ventrikel kanan pada subjek penelitian berupa gelombang $\mathrm{T}$ positif di $V_{1}$ pada keadaan obes (Tabel 2), ternyata menunjukkan perbedaan dan hubungan yang sangat bermakna dibandingkan dengan kelompok gizi normal, khususnya pada kelompok remaja obes lakilaki $(\mathrm{p}<0,001)$.

Abnormalitas EKG berupa hipertrofi ventrikel kanan ditemukan pada 27 (21,4\%) subjek, hipertrofi 
Shinta Larasaty dkk: Hubungan obesitas remaja dengan hipertrofi ventrikel kanan berdasarkan pemeriksaan elektrokardiografi

Tabel 1. Karakteristik subjek penelitian

\begin{tabular}{lcccc}
\hline \multirow{2}{*}{ Karakteristik } & \multicolumn{2}{c}{ Laki-laki } & \multicolumn{2}{c}{ Perempuan } \\
\cline { 2 - 5 } & Obesitas & Gizi normal & Obesitas & Gizi normal \\
& $\mathrm{n}=33$ & $\mathrm{n}=32$ & $\mathrm{n}=30$ & $\mathrm{n}=31$ \\
\hline Durasi obesitas (tahun) & $4(2-10)$ & - & $6(2-10)$ & - \\
Usia (tahun) & $13,5(12-14)$ & $13(12-15)$ & $13(12-14)$ & $13,6(12-14)$ \\
Laju denyut jantung (kali /menit) & $98(69-125)$ & $83(68-115)$ & $103(75-146)$ & $84(66-110)$ \\
Tekanan sistolik (mmHg) & $127(101-180)$ & $107(79-120)$ & $127(92-179)$ & $109(82-125)$ \\
Tekanan diastolik (mmHg) & $81(59-133)$ & $72(60-88)$ & $84(67-114)$ & $68(59-81)$ \\
\hline
\end{tabular}

Keterangan: hasil ditampilkan dalam median (rentang)

Tabel 2. Hubungan jenis kelamin dengan hipertrofi ventrikel kanan

\begin{tabular}{|c|c|c|c|c|c|}
\hline \multirow[b]{2}{*}{ Kriteria } & \multicolumn{2}{|c|}{ Obesitas } & \multirow[b]{2}{*}{$\mathrm{P}^{*}$} & \multicolumn{2}{|c|}{ Gizi normal } \\
\hline & $\begin{array}{c}\begin{array}{c}\text { Laki-laki } \\
(\mathrm{n}=33)\end{array}\end{array}$ & $\begin{array}{l}\text { Perempuan } \\
(\mathrm{n}=30)\end{array}$ & & $\begin{array}{c}\text { Laki-laki } \\
(\mathrm{n}=32)\end{array}$ & $\begin{array}{l}\text { Perempuan } \\
(\mathrm{n}=31)\end{array}$ \\
\hline $\mathrm{RV} 1>\mathrm{ULN}$ & 0 & 0 & & 0 & 0 \\
\hline SV6 > ULN & 2 & 1 & 1,000 & 0 & 0 \\
\hline Sumasi RV1 dan SV6 & 1 & 0 & 1,000 & 0 & 0 \\
\hline Rasio R/S di V1 > ULN & 3 & 4 & 0,700 & 0 & 0 \\
\hline Gelombang $\mathrm{T}$ positif di $\mathrm{V} 1$ & 14 & 2 & $<0,001$ & 0 & 0 \\
\hline Deviasi aksis ke kanan & 0 & 0 & & 0 & 0 \\
\hline Pola qR & 0 & 0 & & 0 & 0 \\
\hline Pola RSR' di V1 & 0 & 0 & & 0 & 0 \\
\hline
\end{tabular}

* Uji eksak Fisher, hubungan bermakna jika $\mathrm{p}<0,05$

Tabel 3. Hubungan obesitas dengan hipertrofi ventrikel kanan

\begin{tabular}{lccc}
\hline Interpretasi EKG & $\begin{array}{c}\text { Obesitas } \\
\mathrm{n}=63\end{array}$ & $\begin{array}{c}\text { Gizi normal } \\
\mathrm{n}=63\end{array}$ & $\mathrm{p}^{*}$ \\
\hline Hipertrofi ventrikel kanan & 27 & 0 & $<0,001$ \\
EKG normal & 34 & 62 & \\
\hline
\end{tabular}

* Uji eksak Fisher, hubungan bermakna jika p <0,05; hipertrofi ventrikel kiri ditemukan pada 2 subjek obes laki-laki, dan 1 subjek gizi normal laki-laki

ventrikel kiri pada $3(2,4 \%)$ subjek, sedangkan elektrokardiogram 96 subjek lainnya dalam batas normal (76,2\%). Dengan uji eksak Fisher, didapatkan hubungan yang bermakna antara obesitas dan hipertrofi ventrikel kanan dengan $\mathrm{p}<0,001$ (Tabel 3).

\section{Pembahasan}

Didapatkan hubungan antara obesitas remaja dan hipertrofi ventrikel kanan berdasarkan pemeriksaan EKG. Patofisiologi disfungsi ventrikel pada obesitas diduga akibat insufisiensi respiratorik, karena kekuatan otot inspiratorik berkurang dan compliance paru pada keadaan obesitas berperan dalam hipoventilasi alveolar. ${ }^{11}$ Hipoventilasi alveolar merupakan dasar terjadi hipertensi pulmonal, karena keadaan hipoksia dan hiperkapnia akan menyebabkan perangsangan kemoreseptor berupa vasokonstriksi pembuluh pulmonal. ${ }^{7}$ Hipertensi pulmonal akan menyebabkan peningkatan tekanan dalam ventrikel kanan dan adaptasi miokardium akan ditandai dengan hipertrofi ventrikel kanan. ${ }^{11}$

Kriteria voltase untuk diagnosis hipertrofi ventrikel 
kanan, apabila ditemukan (salah satu) amplitudo $\mathrm{R}$ di $\mathrm{V}_{1}, \mathrm{~S}$ di $\mathrm{V}_{6}$, serta rasio R/S di $\mathrm{V}_{1}$ yang melebihi ULN (dihitung dari garis isoelektrik), ${ }^{12}$ jumlah aljabar $\mathrm{R}$ di $\mathrm{V}_{1}$ dan $\mathrm{S}$ di $\mathrm{V}_{6}$ lebih besar dari $17 \mathrm{~mm},{ }^{9}$ aksis QRS lebih dari $120^{\circ}, 9$ ditemukan gelombang $T$ positif di $\mathrm{V}_{1},{ }^{9,13}$ atau ditemukan pola $\mathrm{qR}$ maupun RSR' pada sandapan prekordium kanan. ${ }^{9,13}$

Berdasarkan kriteria hipertrofi ventrikel kanan, didapatkan bahwa diagnosis terutama ditegakkan apabila ditemukan gelombang $\mathrm{T}$ positif di $\mathrm{V}_{1}$. Gelombang T menggambarkan repolarisasi ventrikel. Berbeda dengan depolarisasi yang lazimnya pasif, repolarisasi membutuhkan energi sel yang besar. Oleh karena itu, gelombang depolarisasi yang datang dan gelombang repolarisasi yang menjauh menghasilkan defleksi positif pada EKG, sehingga pada elektroda yang merekam gelombang dengan defleksi positif pada saat depolarisasi. Pada fase repolarisasi akan tampak pula defleksi yang positif (ditandai dengan gelombang $T$ positif). Pada saat didapatkan gelombang $R$ dengan amplitudo tinggi akan didapatkan gelombang $\mathrm{T}$ positif. ${ }^{9,14}$ Pada penelitian kami amplitudo gelombang $\mathrm{T}$ lebih tinggi pada kelompok obes dibandingkan dengan kelompok gizi normal, disertai amplitudo $\mathrm{R}$ yang tinggi pada sandapan yang sama. Hal tersebut mendukung hasil interpretasi hipertrofi ventrikel, karena amplitudo yang tinggi berhubungan dengan massa otot yang lebih besar.

Kriteria dijumpai gelombang $\mathrm{T}$ positif di $\mathrm{V}_{1}$ untuk hipertrofi ventrikel kanan sangat bermakna, dibandingkan dengan variabel kriteria lainnya, khususnya pada kelompok remaja obes laki-laki $(\mathrm{p}<0,001)$. Pada remaja perempuan didapatkan amplitudo $\mathrm{R}$ dan $\mathrm{S}$ yang lebih rendah dibandingkan dengan remaja laki-laki, terlebih pada remaja perempuan obes. Jarak sandapan EKG menjauh terhadap jantung karena akumulasi lemak dan pertumbuhan payudara menyebabkan rekaman amplitudo $\mathrm{R}$ dan $\mathrm{S}$ yang rendah, sehingga mempengaruhi pula gambaran gelombang $T$ pada sandapan yang sama. ${ }^{15}$

Pola gelombang $S$ dominan di sandapan prekordial kanan $\left(\mathrm{V}_{1}, \mathrm{~V}_{2}\right)$ dan gelombang $\mathrm{R}$ dominan di sandapan prekordial kiri $\left(\mathrm{V}_{5}, \mathrm{~V}_{6}\right)$ ditemukan pada EKG seluruh kelompok subjek penelitian. Secara fisiologi, fase depolarisasi ventrikel dimulai pada septum interventrikulare, kemudian diikuti oleh depolarisasi bagian terbesar ventrikel lainnya. Masa ventrikel kiri lebih besar dibandingkan dengan ventrikel kanan, sehingga ventrikel kiri akan mendominasi kompleks
QRS, dan vektor aliran listrik rata-rata akan mengarah ke kiri dengan sudut $0^{\circ}$ sampai dengan $90^{\circ}$. Oleh karenanya, didapatkan amplitudo $\mathrm{R}$ yang tinggi terutama pada sandapan prekordial kiri $\left(\mathrm{V}_{5}, \mathrm{~V}_{6}\right)$. Sandapan $V_{1}$ dan $V_{2}$ yang terletak di atas ventrikel kanan akan merekam amplitudo $S$ yang dalam, karena aliran listrik bergerak ke arah kiri menjauhi sandapan tersebut. ${ }^{9}$

Gelombang R dan S pada EKG remaja obes menunjukkan amplitudo yang lebih tinggi dibandingkan dengan kelompok gizi normal, khususnya pada kelompok remaja laki-laki obes. Amplitudo yang tinggi berhubungan dengan massa otot yang lebih besar, sehingga peningkatan amplitudo $\mathrm{R}, \mathrm{S}$, serta rasio R/S di sandapan tersebut mungkin disebabkan karena adanya penebalan masa otot jantung (terdapat hipertrofi ventrikel). Berdasarkan kriteria amplitudo gelombang $S$, hasil interpretasi hipertrofi ventrikel kanan hanya didapatkan pada tiga subjek obes, sedangkan dengan kriteria amplitudo gelombang $\mathrm{R}$, tidak ditemukan hasil interpretasi berupa hipertrofi ventrikel kanan. Pada kelompok remaja obes, akumulasi lemak dan jarak sandapan EKG menjauh dari jantung menyebabkan perubahan rekaman amplitudo $\mathrm{R}$ dan $\mathrm{S}$ sehingga didapatkan amplitudo yang rendah, dan berpengaruh terhadap interpretasi kriteria hipertrofi ventrikel. ${ }^{15}$

Kriteria diagnosis hipertrofi ventrikel kanan lainnya adalah aksis QRS yang melebihi $120^{\circ} .{ }^{9}$ Pada kelompok obes didapatkan aksis QRS yang cenderung lebih besar dibandingkan dengan kelompok gizi normal, meskipun demikian, aksis QRS pada kelompok obes dan gizi normal masih berada dalam rentang nilai normal. Hipertrofi ventrikel kanan memerlukan perubahan yang sangat besar pada proporsi-proporsi ventrikel kanan agar dapat mengatasi gaya listrik yang dihasilkan oleh ventrikel kiri yang normalnya lebih dominan. ${ }^{14}$ Hipertrofi ventrikel kiri ditemukan pula pada subjek obes laki-laki. Hipertrofi ventrikel kiri dapat terjadi akibat hipertensi sistemik yang menyertai keadaan obesitas. Daniels $\mathrm{dkk}^{4}$ menemukan bahwa remaja dengan hipertensi mengalami perubahan struktur geometri ventrikel kiri, serta didapatkan hubungan antara peningkatan IMT dan ditemukannya hipertrofi ventrikel kiri berdasarkan pemeriksaan ekokardiografi.

Pada kelompok status gizi normal didapatkan satu subjek laki-laki dengan interpretasi EKG berupa hipertrofi ventrikel kiri berdasarkan amplitudo $R$ dan $S$ serta rasio $R / S$ di $V_{1}$. Hipertrofi ventrikel kiri dapat terjadi karena penambahan massa ventrikel kiri yang 
Shinta Larasaty dkk: Hubungan obesitas remaja dengan hipertrofi ventrikel kanan berdasarkan pemeriksaan elektrokardiografi

fisiologis sebagai bagian dari pertumbuhan jantung di masa pubertas. ${ }^{16}$ Penelitian Janz $\mathrm{dkk}^{16}$ mendapatkan bahwa pada masa pubertas masa ventrikel kiri remaja laki-laki lebih tinggi dibandingkan dengan remaja perempuan. Observasi yang dilakukan dalam kurun waktu lima tahun ketika anak masih prepubertas dan dibandingkan dengan saat pubertas menunjukkan peningkatan masa ventrikel kiri hingga sebesar 62\% pada remaja laki-laki dan $48 \%$ pada remaja perempuan. Morganroth $\mathrm{dkk}^{17}$ menemukan bahwa amplitudo $\mathrm{R}$ dan $S$ meningkat pada remaja normal, sugestif untuk hipertrofi ventrikel kiri, tetapi ketika dikonfirmasi dengan ekokardiografi didapatkan ketebalan septum serta dinding posterobasal ventrikel kiri dalam batas normal sesuai dengan usia.

Keterbatasan penelitian terletak pada tidak dilakukan pengelompokan subjek berdasarkan stadium maturasi seksual untuk analisis amplitudo $\mathrm{R}$ dan S. Subjek penelitian hampir seluruhnya termasuk dalam kelompok usia remaja dini (usia 12-14 tahun 125 subjek), dan hanya satu subjek yang termasuk ke dalam kelompok remaja menengah (usia 15-16 tahun). Namun, pada kelompok remaja usia dini tersebut didapatkan perbedaan stadium maturasi seksual pada tiap-tiap subjek penelitian. Dilaporkan oleh Stafford $\mathrm{dkk}^{15}$ hasil analisis dari 751 EKG anak dan remaja berusia 8-20 tahun (tanpa penyakit kronik, penyakit jantung/paru, deformitas dinding dada) yang datang untuk pemeriksaan rutin, ternyata didapatkan perubahan amplitudo $\mathrm{R}$ dan $\mathrm{S}$ pada kelompok usia remaja. Amplitudo R dan $S$ yang lebih rendah ditemukan pada kelompok dengan maturasi seksual yang lebih tinggi (Tanner 4 dan Tanner 5), khususnya pada kelompok perempuan. Adanya perubahan internal jantung, maturasi seksual seperti pertumbuhan payudara, berkembangnya dinding dan otot dada diduga berperan terhadap perubahan kontur dada, akumulasi jaringan lemak, dan menjauhnya jarak sandapan EKG terhadap jantung karena pertumbuhan payudara. Implikasi klinis dari amplitudo $\mathrm{R}$ dan $\mathrm{S}$ tersebut, yaitu diketahui akan mempengaruhi kriteria hipertrofi ventrikel dan interpretasinya. ${ }^{15}$

Kami juga menemukan bahwa laju denyut jantung kelompok obes lebih tinggi dibandingkan dengan gizi normal. Laju denyut jantung berupa sinus takikardia ditemukan pada 6 subjek obes laki-laki, 12 subjek obes perempuan, 4 subjek gizi normal laki-laki, dan 2 subjek gizi normal perempuan. Berdasarkan patofisiologi, hal tersebut diduga akibat adanya hiperaktivitas sistem saraf simpatis. ${ }^{18}$ Sesuai dengan penelitian Freedman $\mathrm{dkk}^{19}$ yang mendapatkan bahwa laju denyut jantung yang lebih tinggi didapatkan pada remaja dengan obes dibandingkan dengan gizi normal, demikian pula sejalan dengan penelitian yang dilakukan oleh Sürücu $\mathrm{dkk}^{20}$ terhadap remaja obes.

Rerata tekanan sistolik dan diastolik pada kelompok laki-laki obes maupun perempuan obes berada di atas rata-rata persentil 90 kurva tekanan darah. Pada kelompok gizi normal laki-laki dan perempuan didapatkan bahwa rerata tekanan darah sistolik dan diastolik berada pada rentang normal (antara persentil 5 hingga persentil 90 kurva tekanan darah). Freedman $\mathrm{dkk}^{19}$ melaporkan bahwa subjek obes berisiko 4,5 kali lebih tinggi untuk mengalami peningkatan tekanan darah sistolik dan berisiko 2,4 kali lebih tinggi untuk mengalami peningkatan tekanan darah diastolik. Hipertensi pada obesitas merupakan kombinasi faktor yang meliputi resistensi insulin, hiperaktivitas sistem saraf simpatis, aktivasi sistem renin-angiotensin yang menyebabkan peningkatan reabsorbsi natrium dan berkurangnya natriuresis, serta abnormalitas struktur dan fungsi pembuluh darah. ${ }^{11}$

Disimpulkan bahwa hipertrofi ventrikel kanan pada remaja obes, dengan kriteria diagnosis berupa gelombang $\mathrm{T}$ positif di $\mathrm{V}_{1}$ pada $\mathrm{EKG}$, khususnya pada remaja obes laki-laki. Disarankan agar EKG dapat dipertimbangkan pada remaja obes untuk penapisan adanya hipertrofi ventrikel kanan dan konfirmasi diagnosis dapat dilakukan dengan pemeriksaan lanjutan berupa ekokardiografi. Perlu dipertimbangkan mengenai faktor maturasi seksual dalam pemilihan subjek untuk penelitian selanjutnya.

\section{Daftar pustaka}

1. WHO. Obesity: preventing and managing the global epidemic. Geneva: WHO Technical Report Series; 2000.

2. Soegih R. Tren obesitas: dulu, sekarang, dan yang akan datang. Dalam: Soegih R, Wiramihardja KK, penyunting. Obesitas: permasalahan dan terapi praktis. Jakarta: CV Sagung Seto; 2009.h.1-7.

3. Pardede N. Masa remaja. Dalam: Narendra MB, Sularyo TS, Soetjiningsih, Suyitno H, Ranuh IG, penyunting. Bandung: Sagung Seto; 2002.h.138-70.

4. Daniels SR, Arnett DK, Eckel RH, Gidding SS, Hayman LL, Kumanyika S, dkk. Overweight in children and 
Shinta Larasaty dkk: Hubungan obesitas remaja dengan hipertrofi ventrikel kanan berdasarkan pemeriksaan elektrokardiografi

adolescents: pathophysiology, consequences, prevention, and treatment. Circulation 2005;111:1999-2012.

5. Zeybek C, Aktuglu-Zeybek C, Onal H, Altay S, Erdem A, Celebi A. Right ventricular subclinical diastolic dysfunction in obese children: the effect of weight reduction with a low-carbohydrate diet. Pediatr Cardiol 2009;30:946-53.

6. Wong CY, O'Moore-Sullivan T, Leano R, Hukins C, Jenkins C, Marwick TH. Association of subclinical right ventricular dysfunction with obesity. J Am Coll Cardiol 2006;47:611-6.

7. Abel ED, Litwin SE, Sweeney G. Cardiac remodeling in obesity. Physiol Rev 2008;88:389-419.

8. Puchalski MD, Lozier JS, Bradley DJ, Minich LL, Tani LY. Electrocardiography in the diagnosis of right ventricular hypertrophy in children. Pediatrics 2006;118:1052-5.

9. Park MK. Pediatric cardiology for practitioner. Edisi ke-5. Philadelphia: Mosby Elsevier; 2008.h.52-7.

10. Dickinson DF. The normal ECG in childhood adolescence. Heart 2005;91:1626-30.

11. Mokhlesi B, Tulaimat A. Recent advances in obesity hypoventilation syndrome. Chest 2007;132:1322-36.

12. Hancock EW, Deal BJ, Mirvis DM, Okin P, Kligfield P, Gettes LS. AHA/ACCF/HRS recommendations for the standardization and interpretation of the electrocardiogram. Circulation 2009;119:e251-61.
13. Wahab AS. Penyakit jantung anak. Edisi ke-3. Jakarta: ECG; 2003. hlm. 39-40.

14. Thaler MS. Electrocardiography. Edisi ke-2. Jakarta: Penerbit Hipokrates; 2000.

15. Stafford EM, Weir MR, Pearl W, Imai W, Schydlower M, Gregory G. Sexual maturity rating: a marker for effects of pubertal maturation on the adolescent electrocardiogram. Pediatrics 1989;83:565-9.

16. Janz KF, Dawson JD, Mahoney LT. Predicting heart growth during puberty. Pediatrics 2000;105:1-8.

17. Morganroth J, Maron BJ, Krovetz LJ, Henry WL, Epstein SE. Electrocardiographic evidence of left ventricular hypertophy in otherwise normal children, clarification by echocardiography. Am J Cardiol 1975;35:278-81.

18. Sorof J, Daniels S. Obesity hypertension in children: a problem of epidemic proportions. Hypertension 2002;40:441-7.

19. Freedman DS, Dietz WH, Srinivasan SR, Berenson GS. The relation of overweight to cardiovascular risk factors among children and adolescents: the bogalusa heart study. Pediatrics 1999;103:1175-82.

20. Sürücu H, Tath E, Okudan S, Degirmenci A. Evaluation of the effect of obesity on heart function using standard echocardiography and pulsed wave tissue doppler imaging. Southern Med J 2008;101:152-7. 